\title{
Pengaruh Posisi Lereng terhadap Sifat Fisika dan Kimia Tanah pada Inceptisols di Jatinangor
}

\author{
Mahfud Arifin1), Novarina Darmawan Putri²), Apong Sandrawati1), dan Rachmat Harryanto ${ }^{1)}$ \\ 1) Departemen Ilmu Tanah dan Sumberdaya Lahan, Fakultas Pertanian Universitas Padjadjaran \\ 2) Alumni Program Studi Agroteknologi, Fakultas Pertanian Universitas Padjadjaran \\ Jl. Raya Bandung Sumedang Km 21 Jatinangor \\ Korespondensi: mahfud.arifin@unpad.ac.id; novarinadp1234@gmail.com
}

\begin{abstract}
Slope held a vital role in soil formation and development through erosion, transportation, and deposition. The degree of the slope determines the flow rate and volume of surface water, while the slope position determines rate of the erosion. The research aimed to understand the impact of the slope position against physical (texture, Bulk Density, top soil thickness,) and chemical (pH, Organic carbon, and cation exchange capacity (CEC)) and the correlation between the top soil thickness to physical and soil chemical properties. The research was conducted in April to June 2016. The soil samples were taken from 15-25\% slope and three positions: upper slope, middle slope and lower slope. Each slope was repeated 5 times, hence 15 spots of soil samples were obtained. This research used descriptive comparative method and stratified purpose sampling as the sampling technique. The results of T-Student test showed that the slope position influenced the topsoil thickness of 6.91 point in the upper and middle slope and 3.89 point in the middle and lower slope. The results of the correlation test in each parameter in the upper hill showed there was correlation between top soil against dust fraction ( $r=0.826$ ), top soil against clay fraction ( $r=0.823)$, and top soil against soil CEC $(r=0.787)$. The middle slope showed there was correlation between top soil and soil $p H(r=0.872)$ and topsoil to soil CEC $(r=0.790)$. The lower slope showed there was correlation between top soil and soil $p H(r=0.870)$.
\end{abstract}

Key words: soil erosion, Inceptisols, slope position, topsoil

\section{PENDAHULUAN}

Tanah dalam bidang pertanian diartikan sebagai media tempat tumbuhnya tanaman. Tanah berasal dari hasil pelapukan batuan bercampur dengan sisa-sisa bahan organik dan organisme (vegetasi atau hewan) yang hidup di atasnya atau di dalamnya. Selain itu di dalam tanah terdapat juga air dan udara. Air dalam tanah berasal dari air hujan yang ditahan oleh tanah sehingga tidak meresap ke tempat lain. Disamping percampuran bahan mineral dengan bahan organik, maka dalam proses pembentukan tanah terbentuk pula lapisan-lapisan tanah atau horizon. Definisi tanah adalah kumpulan dari benda alam di permukaan bumi yang tersusun dalam horizon-horizon, terdiri dari campuran bahan mineral, bahan organik, air, udara, dan merupakan media untuk tumbuhnya tanaman (Hardjowigeno, 2010).

Menurut Sutanto (2005), kemampuan tanah sebagai habitat tanaman dan menghasilkan bahan yang dapat dipanen sangat ditentukan oleh tingkat kesuburan tanah. Kesuburan tanah merupakan faktor penting yang dibutuhkan tanaman untuk dapat bertahan hidup dan berproduksi baik. Kesuburan tanah sangat ditentukan oleh ketersediaan dan jumlah hara yang ada di dalam tanah. Di lahan pertanian, kadar hara tanah merupakan fungsi dari bahan induk, iklim, topografi, organisme, vegetasi, dan waktu.

Lereng merupakan parameter topografi, dimana lereng memiliki pengaruh yang besar terhadap pengolahan atau penggunaan suatu lahan. Hal ini disebabkan karena sifat faktorfaktor pembentuk tanah yang berbeda di setiap tempat. Menurut Hardjowigeno (2010) hubungan lereng dengan sifat-sifat tanah tidak selalu sama di semua tempat. Sebagai salah satu komponen topografi, lereng berperan penting dalam proses pembentukan dan perkembangan tanah melalui proses erosi, 
transportasi dan deposisi. Pada daerah yang tererosi, sifat-sifat tanah akan mengalami perubahan Kerusakan yang dialami pada tanah yang mengalami erosi berupa kemunduran sifat-sifat fisik dan kimia. Pengaruh besarnya erosi terhadap penurunan produksi tergantung dari jenis tanaman dan perubahan sifat-sifat fisik dan kimia menurut kedalaman tanah.

Lereng memiliki beberapa unsur diantaranya kemiringan, arah, panjang dan posisi lereng. Kemiringan lereng menentukan besarnya kecepatan aliran permukaan dan volume air, sedangkan posisi lereng menentukan besar kecilnya erosi (Asdak, 2002). Pada lereng atas adanya tumbukan air hujan menyebabkan hancurnya agregat tanah. Partikel tanah yang terlepas diangkut oleh aliran permukaan menuruni lereng. Pada lereng yang lebih bawah, erosi terjadi lebih besar karena adanya tumbukan air hujan dan aliran permukaan dari lereng atasnya sehingga tanah yang terangkut lebih banyak. Selama terjadi aliran permukaan, air akan terkumpul di lereng bawah dan akan terjadi pengendapan dari tana yang tererosi. Hal tersebut mengakibatkan permukaan tanah di lereng bawah lebih tebal sehingga lereng bawah akan memiliki sifat fisik dan kimia tanah yang lebih baik dibandingkan dengan lereng atasnya. Pengaruh akibat terjadinya erosi akan menyebabkan perubahan dan terganggunya sifat-sifat fisik dan kimia tanah.

\section{METODOLOGI}

Penelitian terdiri atas kegiatan pengamatan di lapangan dan analisis di laboratorium. Lokasi survei lapangan dilaksanakan di lahan Ciparanje, Kecamatan Jatinangor, Kabupaten Sumedang, Jawa Barat. Kegiatan analisis sifat-sifat tanah dilakukan di laboratorium Departemen Ilmu Tanah dan Sumberdaya Lahan, Fakultas Pertanian UNPAD.

Bahan-bahan yang digunakan adalah peta dasar dan peta tematik, berupa peta topografi, peta kemiringan lereng, peta curah hujan, peta penggunaan lahan, dan peta geologi. Bahan lain yang digunakan adalah bahan kimia yang digunakan pada saat analisis sifat-sifat tanah di laboratorium.

Peralatan kerja lapangan yang digunakan adalah GPS, klinometer, bor tanah, cangkul, pisau, kertas deskripsi tanah, ring sampler, kantong plastik, meteran, alat tulis, label, dan kamera. Peralatan kerja studio yang digunakan adalah laptop yang memiliki Softwae ArcGIS 10.1, Microsoft Office 2007, dan SPSS 2.0.

Objek utama penelitian ini adalah lereng dengan kemiringan 15 - $25 \%$. Pengamatan dilakukan pada 3 (tiga) posisi lereng, yaitu: atas, tengah, dan bawah. Pengambilan contoh tanah dilakukan pada masing-masing posisi lereng tersebut dengan jumlah contoh tanah 5 contoh per posisi lereng.

Tahap pertama adalah studi pustaka dan pengumpulan data-data sekunder yang dibutuhkan berupa peta-peta dasar. Kemudian dilakukan penentuan pengambilan dan jumlah titik sampel tanah. Tahap kedua yaitu pra survey dilakukan untuk melihat dan mencari daerah yang cocok dan dapat mewakili daerah tersebut untuk dilakukan penelitian. Dengan tiga posisi lereng dan dilakukan lima kali ulangan sehingga mendapatkan 15 titik pengamatan. Hasil dari kegiatan pra survei ini berupa arahan mengenai lokasi yang sesuai dengan tujuan penelitian.

Tahap survei dilakukan dengan mengamati kondisi lapangan dan mengambil sampel tanah. Pengambilan contoh tanah pada setiap titik pengamatan dilakukan dengan menggunakan bor untuk sampel tekstur, $\mathrm{pH}$ tanah, KTK tanah, dan C-organik tanah, diambil pada kedalaman 0-30 $\mathrm{cm}$ dan untuk pengambilan sampel bobot isi menggunakan ring sampler yang selanjutnya akan diuji ke laboratorium. Untuk pengamatan ketebalan topsoil dilakukan di lapangan dengan membuat minipit.

Tahap terakhir adalah tahap pengolahan data. Pada tahap ini dilakukan uji statistik TStudent untuk mengetahui perbedaan nilai- 
nilai dari parameter tanah yang diamati pada posisi lereng yang berbeda. Selanjutnya dilakukan uji regresi untuk mengetahui hubungan antara ketebalan topsoil dengan parameter tanah.

\section{HASIL DAN PEMBAHASAN}

\subsection{Kondisi Umum Tempat Penelitian}

Penelitian ini dilakukan di lahan Ciparanje Universitas Padjadjaran 107076'83,9" BT 107076'90,7" BT dan 06'91'21,9" LS 06091'31,4" LS. Lokasi penelitian terletak di kaki Gunung Manglayang, Desa Cileles, Kecamata Jatinangor, Kabupaten Sumedang.

Lokasi penelitian berada pada ketinggian antara 830 - $863 \mathrm{M}$ dpl. Kemiringan lereng pada wilayah ini adalah 0-8\% (datar), 8-15\% (landai), $15-25 \%$ (agak curam), 25-40\% (curam), dan $>40 \%$ (sangat curam). Kemiringan lereng 15-25\% memiliki luas 2,07 Ha. Jenis tanah pada daerah penelitian adalah Inceptisols.

Berdasarkan data curah hujan dalam kurun waktu 2005-2015 menunjukkan bahwa lahan Ciparanje memiliki rata-rata curah hujan 2.210,69 mm/tahun. Lahan Ciparanje memiliki penggunaan lahan yang beragam yaitu sawah tadah hujan, sawah irigasi, kebun campuran, padang rumput, hutan campuran, semak belukar, bangun dan sebagainya. Lahan hutan campuran di lokasi penelitian didominasi oleh tanaman tahunan dan semak.

\subsection{Pengaruh Posisi Lereng terhadap Sifat Fisik Tanah}

Sifat fisika tanah yang diukur adalah fraksi tanah (pasir, debu, dan liat), ketebalan top soil, dan bobot isi. Analisis t-student dilakukan untuk mengetahui pengaruh antara sifat fisik tanah pada lereng atas, lereng tengah dan lereng bawah. Tabel 1 merupakan hasil analisis beda nyata terhadap persentase fraksi tanah (pasir, debu, dan liat). Hasil analisis menunjukkan bahwa posisi lereng tidak berpengaruh nyata terhadap persentasi fraksifraksi tanah baik pasir, debu ataupun liat.
Tabel 1 Pengaruh posisi lereng terhadap fraksi tanah (pasir, debu, dan liat)

\begin{tabular}{lccc}
\hline $\begin{array}{c}\text { Posisi } \\
\text { Lereng }\end{array}$ & Pasir (\%) & Debu (\%) & Liat (\%) \\
\hline Atas & $7,58 \mathrm{a}$ & $45,3 \mathrm{a}$ & $39,2 \mathrm{a}$ \\
Tengah & $8,20 \mathrm{a}$ & $47,0 \mathrm{a}$ & $35,6 \mathrm{a}$ \\
\hline Tengah & $8,20 \mathrm{a}$ & $47,0 \mathrm{a}$ & $35,6 \mathrm{a}$ \\
Bawah & $8,06 \mathrm{a}$ & $41,2 \mathrm{a}$ & $42,6 \mathrm{a}$ \\
\hline Atas & $7,58 \mathrm{a}$ & $45,3 \mathrm{a}$ & $39,2 \mathrm{a}$ \\
Bawah & $8,06 \mathrm{a}$ & $41,2 \mathrm{a}$ & $42,6 \mathrm{a}$ \\
\hline Keterangan $:$ & Angka-angka yang diikuti huruf yang \\
& $\begin{array}{l}\text { sama menunjukan tidak berbeda } \\
\text { nyata. Angka dengan hurut berbeda }\end{array}$ \\
& $\begin{array}{l}\text { menyatakan berbeda nyata menurut } \\
\text { uji T-Student pada taraf kepercayaan } \\
\text { 95\%. }\end{array}$
\end{tabular}

Asdak (2002) menyatakan bahwa fraksi liat menjadi indikator tingkat erosi. Liat merupakan fraksi dengan ukuran terkecil sehingga lebih mudah ditransportasikan pada saat kejadian erosi. Hal ini akan berpengaruh kepada tingginya persentase liat pada posisi lereng bawah. Berdasarkan hasil pengukuran, nilai persentase liat lebih tinggi di posisi lereng bawah, namun secara statistik tidak menunjukkan perbedaan yang nyata. Penambahan jumlah ulangan contoh tanah dapat disarankan untuk pelaksanaan penelitian selanjutnya.

Pengaruh erosi dapat dilihat dari ketebalan topsoil (Arsyad, 2010). Berdasarkan Tabel 2 ketebalan topsoil di lereng atas dengan lereng tengah berbeda nyata dan ketebalan topsoil di lereng tengah dengan lereng bawah berbeda nyata. Sedangkan, pada lereng atas dengan lereng bawah tidak beda nyata. Posisi lereng atas merupakan lereng yang memiliki nilai rata-rata ketebalan topsoil yang lebih tinggi dibandingkan dengan posisi lereng tengah dan lereng bawah. Posisi lereng tengah merupakan lereng yang memiliki nilai ratarata ketebalan topsoil yang paling rendah dibandingkan dengan lereng atas dan lereng bawah.

Pada lereng bawah proses erosi yang terjadi tidak sebesar di lereng tengah serta terdapatnya deposisi partikel tanah dari lereng atasnya sehingga pada posisi lereng ini memiliki topsoil yang tebal. Menurut Arsyad 
(2010) lereng yang semakin curam akan memperbesar kecepatan aliran permukaan yang akan memperbesar energi angkut permukaan. Energi terbesar dari aliran permukaan akan terjadi pada lereng tengah, dimana posisi lereng ini sebagai area transportasi. Oleh karena itu, kehilangan topsoil akan lebih tinggi pada lereng tengah (ketebalan topsoil paling rendah).

Tabel 1 Pengaruh posisi lereng terhadap ketebalan topsoildan bobot isi tanah

\begin{tabular}{ccc}
\hline $\begin{array}{c}\text { Posisi } \\
\text { Lereng }\end{array}$ & $\begin{array}{c}\text { Top soil } \\
(\mathrm{cm})\end{array}$ & $\begin{array}{c}\text { Bobot Isi } \\
\left(\mathrm{g} / \mathrm{cm}^{3}\right)\end{array}$ \\
\hline Atas & $31,54 \mathrm{~b}$ & $1,18 \mathrm{a}$ \\
Tengah & $18,98 \mathrm{a}$ & $1,15 \mathrm{a}$ \\
\hline Tengah & $18,98 \mathrm{a}$ & $1,15 \mathrm{a}$ \\
Bawah & $29,58 \mathrm{~b}$ & $1,17 \mathrm{a}$ \\
\hline Atas & $31,54 \mathrm{a}$ & $1,18 \mathrm{a}$ \\
Bawah & $29,58 \mathrm{a}$ & $1,17 \mathrm{a}$ \\
\hline Keterangan : & $\begin{array}{l}\text { Angka-angka yang diikuti huruf yang } \\
\text { sama menunjukan tidak berbeda nyata. }\end{array}$ \\
& $\begin{array}{c}\text { Angka dengan huruf berbeda menyata- } \\
\text { kan berbeda nyata menurut uji T- }\end{array}$ \\
& Student pada taraf kepercayaan 95\%
\end{tabular}

Parameter sifat fisika lain yang diamati adalah nilai bobot isi tanah. Berdasarkan Tabel 2 posisi lereng tidak berpengaruh terhadap nilai bobot isi tanah. Bobot isi tanah sering diintrepretasikan sebagai nilai kepadatan tanah yang dipengaruhi oleh beberapa faktor, seperti: pengolahan tanah, tekstur, kadar bahan organik (C-organik), stuktur, dan kadar air tanah (Sarief, 1989). Dalam hal ini, proses erosi tidak berpengaruh langsung terhadap nilai bobot isi. Salah satu faktor yang dipertimbangkan adalah tekstur dan nilai persentase fraksi tanah. Berdasarkan analisis pada Tabel 1, posisi lereng tidak berpengaruh terhadap nilai persentase fraksi tanah, oleh karena itu, nilai bobot isi juga tidak berbeda nyata.

\subsection{Pengaruh Posisi Lereng terhadap Sifat Kimia Tanah}

Sifat kimia yang dianalisis adalah Corganik, pH, dan KTK. Hasil analisis statistik uji T-student (Tabel 3) menunjukkan bahwa posisi lereng tidak berpengaruh nyata terhadap sifat-sifat kimia tanah baik kadar Corganik, $\mathrm{pH}$ tanah, maupun KTK tanah.

Bahan organik merupakan salah satu sifat tanah yang dapat mempengaruhi erosi (Arsyad, 2010). Banuwa dan Buchari (2010) menambahkan bahwa salah satu material yang terangkut pada saat erosi di permukaan tanah adalah bahan organik (yang dapat dinyatakan dalam \% C-organik). Pada proses erosi, bahan organik berupa fraksi koloid tanah terangkut bersama dengan liat dan debu halus (fraksi halus) dalam bentuk agregat tanah. Oleh karena itu, kadar bahan organik yang tidak berbeda nyata pada setiap posisi lereng sejalan dengan jumlah fraksi halus yang juga tidak berbeda nyata.

Tabel 3 Pengaruh posisi lereng terhadap sifat kimia tanah ( $\mathrm{pH}, \mathrm{C}$-organik, dan KTK)

\begin{tabular}{lccc}
\hline $\begin{array}{r}\text { Posisi } \\
\text { Lereng }\end{array}$ & $\begin{array}{c}\text { C-organik } \\
(\%)\end{array}$ & pH & $\begin{array}{c}\text { KTK } \\
(\mathrm{me} / 100 \mathrm{~g})\end{array}$ \\
\hline Atas & $0,47 \mathrm{a}$ & $6,19 \mathrm{a}$ & $22,34 \mathrm{a}$ \\
Tengah & $0,42 \mathrm{a}$ & $6,25 \mathrm{a}$ & $22,98 \mathrm{a}$ \\
\hline Tengah & $0,42 \mathrm{a}$ & $6,25 \mathrm{a}$ & $22,98 \mathrm{a}$ \\
Bawah & $0,46 \mathrm{a}$ & $6,49 \mathrm{a}$ & $23,09 \mathrm{a}$ \\
\hline Atas & $0,47 \mathrm{a}$ & $6,19 \mathrm{a}$ & $22,34 \mathrm{a}$ \\
Bawah & $0,46 \mathrm{a}$ & $6,49 \mathrm{a}$ & $23,09 \mathrm{a}$ \\
\hline
\end{tabular}

Keterangan : Angka-angka yang diikuti huruf yang sama menunjukan tidak berbeda nyata menurut uji T-Student pada taraf kepercayaan $95 \%$.

Berdasarkan Tabel 3, nilai rata-rata $\mathrm{pH}$ tanah pada lokasi penelitian cenderung rendah namun pada lereng bawah dengan nilai $\mathrm{pH}$ 6,49 dapat dikatakan netral. Nilai pH tidak berbeda nyata pada posisi lereng yang berbeda. Salah satu faktor yang mempengaruhi kemasaman $(\mathrm{pH})$ tanah adalah nilai C-organik (Thomas and Hargrove, 1984). Nilai $\mathrm{pH}$ yang tidak berbeda nyata pada setiap posisi lereng sejalan dengan nilai C-organik yang tidak berbeda nyata juga.

Nilai KTK tanah pada lokasi penelitian cukup tinggi, berkisar antara 20,49-26,42 
me/100 g. Menurut Hardjowigeno (2010) nilai KTK tanah dipangaruhi oleh kandungan bahan organik dan jenis liat. Indranada (1994) menambahkan bahwa KTK pada tanah di lingkungan tropis juga dipengaruhi oleh $\mathrm{pH}$. Hal ini disebabkan adanya muatan variabel yang tergantung $\mathrm{pH}$ ( $\mathrm{pH}$ dependent charge) selain muatan permanen tanahnya. Nilai Corganik dan $\mathrm{pH}$ yang tidak berbeda nyata pada setiap posisi lereng sejalan dengan nilai KTK yang tidak berbeda nyata.

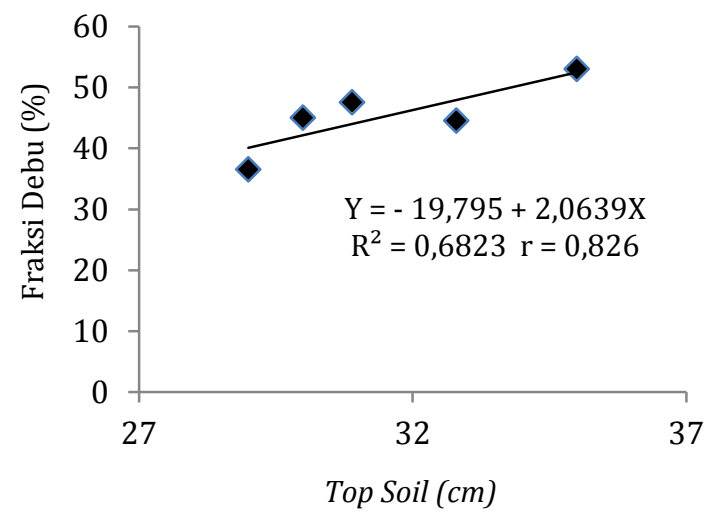

a

\subsection{Hubungan antar Parameter}

\subsubsection{Ketebalan Topsoil dengan Tekstur Tanah}

Hasil analisis regresi menunjukkan bahwa terdapat hubungan antara ketebalan Topsoildengan fraksi debu dan ketebalan Topsoildengan fraksi liat di lereng atas. Hubungan antara ketebalan Topsoildengan fraksi debu dan liat dapat dilihat pada Gambar 1.

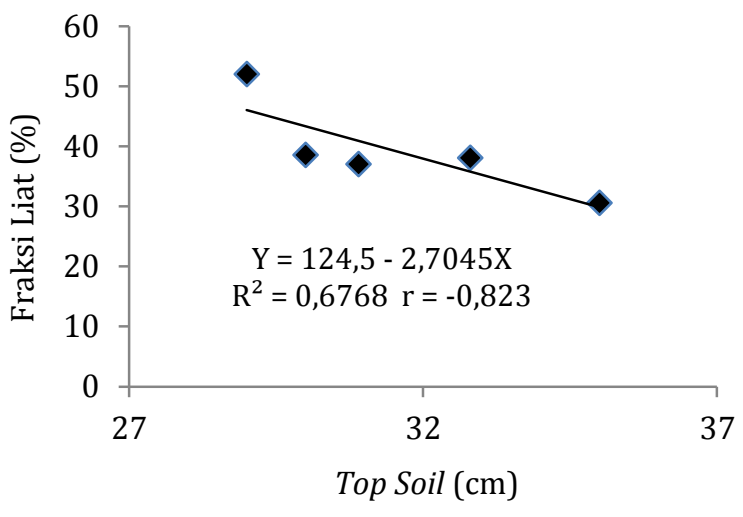

b

Gambar 1 Hubungan Ketebalan Topsoildengan Fraksi Debu di Lereng Atas (a), Fraksi Liat di Lereng Atas (b)

Berdasarkan Gambar 1 (a) Koefisien korelasi dengan nilai $r=0,826$ menunjukkan bahwa terdapat hubungan yang kuat antara ketebalan topsoildengan fraksi debu pada lereng atas. Nilai $\mathrm{R}^{2}$ menunjukkan bahwa ketebalan topsoilmemengaruhi fraksi debu sebesar $68,2 \%$ dan sisanya dipengaruhi oleh faktor lain, dimana hubungan yang terjadi pada posisi lereng atas adalah semakin tebal topsoilmaka semakin tinggi persentase fraksi debu pada daerah tersebut. Terdapatnya hubungan disebabkan karena fraksi debu merupakan partikel atau bahan tanah yang peka terhadap erosi. Pada posisi lereng atas banyak air ditahan dipermukaan tanah sehingga pada bagian ini merupakan lereng yang paling stabil. Pada bagian lereng atas erosi belum terlalu kuat sehingga fraksi debu kemungkinan akan lebih tinggi di lereng atas dibandingkan dengan posisi lereng lainnya.
Gambar 1 (b) menjelaskan Koefisien korelasi dengan nilai $r=-0,823$ menunjukkan bahwa terdapat hubungan yang kuat antara ketebalan topsoildengan fraksi liat pada lereng atas. Kandungan fraksi liat sebesar $67,7 \%$ dipengaruhi oleh ketebalan topsoildan sisanya dipengaruhi oleh faktor lain yang belum diketahui. Hubungan yang terjadi pada posisi lereng atas adalah semakin tebal topsoilmaka semakin rendah persentase fraksi liat pada daerah tersebut.

Menurut Hardjowigeno (2010) tanahtanah dengan tekstur kasar seperti pasir dapat tahan terhadap erosi karena memilki butiranbutiran yang besar (kasar) sehingga memerlukan lebih banyak tenaga untuk mengangkutnya. Begitu pula pada tanah dengan tekstur halus seperti liat, tahan terhadap erosi karena daya kohesi yang kuat dari liat tersebut sehingga gumpalan- 
gumpalannya sulit dihancurkan. Tekstur tanah yang paling peka terhadap erosi adalah pasir sangat halus dan debu. Oleh sebab itu maka semakin tinggi kandungan debu dalam tanah maka akan semakin peka tanah tersebut terhadap erosi.

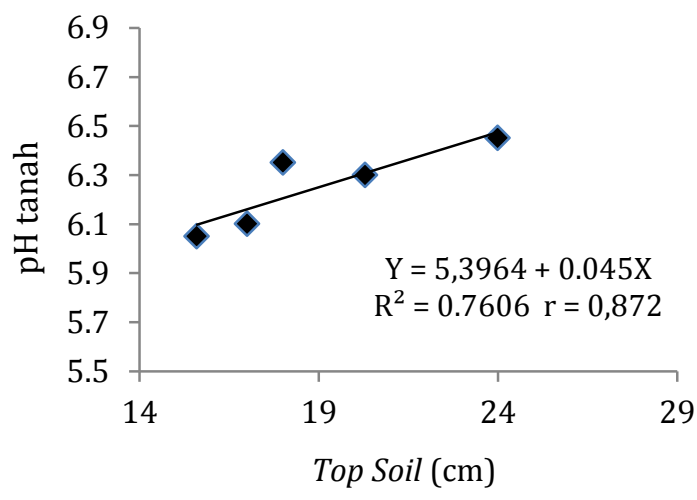

a

\subsubsection{Hubungan antara Ketebalan Topsoildengan $\mathrm{pH}$ tanah}

Hasil analisis regresi hubungan antara ketebalan topsoil dengan $\mathrm{pH}$ tanah di lereng atas adalah terdapat hubungan yang kuat antara parameter tersebut (Gambar 2).

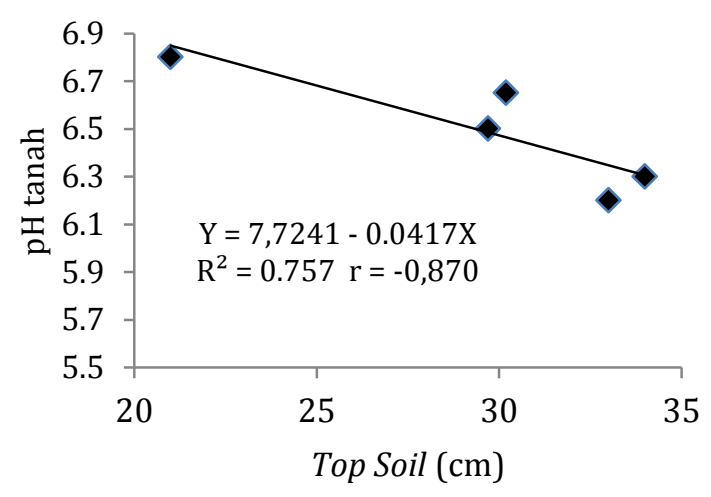

$\mathrm{b}$

Gambar 2 Hubungan Ketebalan Topsoildengan pH Tanah di Lereng Tengah (a), Lereng Bawah (b)

Berdasarkan Gambar 2 (a) Koefisien korelasi dengan nilai $r=0,872$ menunjukkan bahwa terdapat hubungan yang kuat antara ketebalan topsoil dengan $\mathrm{pH}$ tanah pada lereng tengah. Berdasarkan hasil analisis maka dapat dinyatakan bahwa pada posisi lereng tengah, semakin tebal topsoil maka semakin tinggi nilai $\mathrm{pH}$ tanah pada daerah tersebut.

Gambar 2 (b) menjelaskan bahwa koefisien korelasi dengan nilai $r=-0,870$ menunjukkan bahwa terdapat hubungan yang kuat antara ketebalan topsoil dengan $\mathrm{pH}$ tanah pada lereng bawah, dimana nilai $\mathrm{pH}$ tanah sebesar $75,7 \%$ dipengaruhi oleh ketebalan topsoil dan sisanya dipengaruhi oleh faktor lain. Hubungan yang terjadi pada posisi lereng bawah adalah semakin tebal topsoil maka semakin rendah nilai $\mathrm{pH}$ tanah pada daerah tersebut.

Posisi lereng bawah merupakan tempat dimana terjadinya proses sedimentasi bahanbahan tanah dan air dari lereng diatasnya, pada posisi ini nilai $\mathrm{pH}$ tanah akan semakin rendah karena terdapat ionisasi air. Pada kondisi ini, muatan-muatan negatif yang kosong akibat hilangnya basa-basadd yang umumnya berikatan dengan hidroksil hasil ionisasi air meninggalkan ion $\mathrm{H}$, yang kemudian menduduki muatan-muatan permukaan koloid. Akibatnya melalui proses

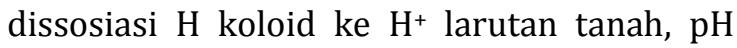
tanah menjadi turun (Hanafiah, 2007).

Menurut Hanafiah (2007) nilai pH tanah dipengaruhi oleh dekomposisi bahan organik, bahan induk, pengendapan, vegetasi dan kedalaman tanah. Aktivitas dari mikroorganisme untuk mendekomposisikan bahan organik banyak terjadi pada lapisan top soil, dari hasil dekomposisi tersebut dapat memengaruhi nilai pH tanah. Pada lahan dengan curah hujan tinggi, umumnya kemasaman tanahnya dapat meningkat sesuai dengan kedalaman lapisan tanah, sehingga kehilangan topsoil karena erosi dapat menyebabkan tanah menjadi lebih masam.

\subsubsection{Hubungan antara Ketebalan Topsoil dengan KTK Tanah}

Hasil analisis regresi hubungan antara ketebalan topsoil dengan KTK tanah adalah terdapat hubungan yang kuat antara kedua variabel tersebut. Hubungan antara ketebalan topsoildengan KTK tanah di lereng atas dan tengah dapat dilihat dari Gambar 3. 

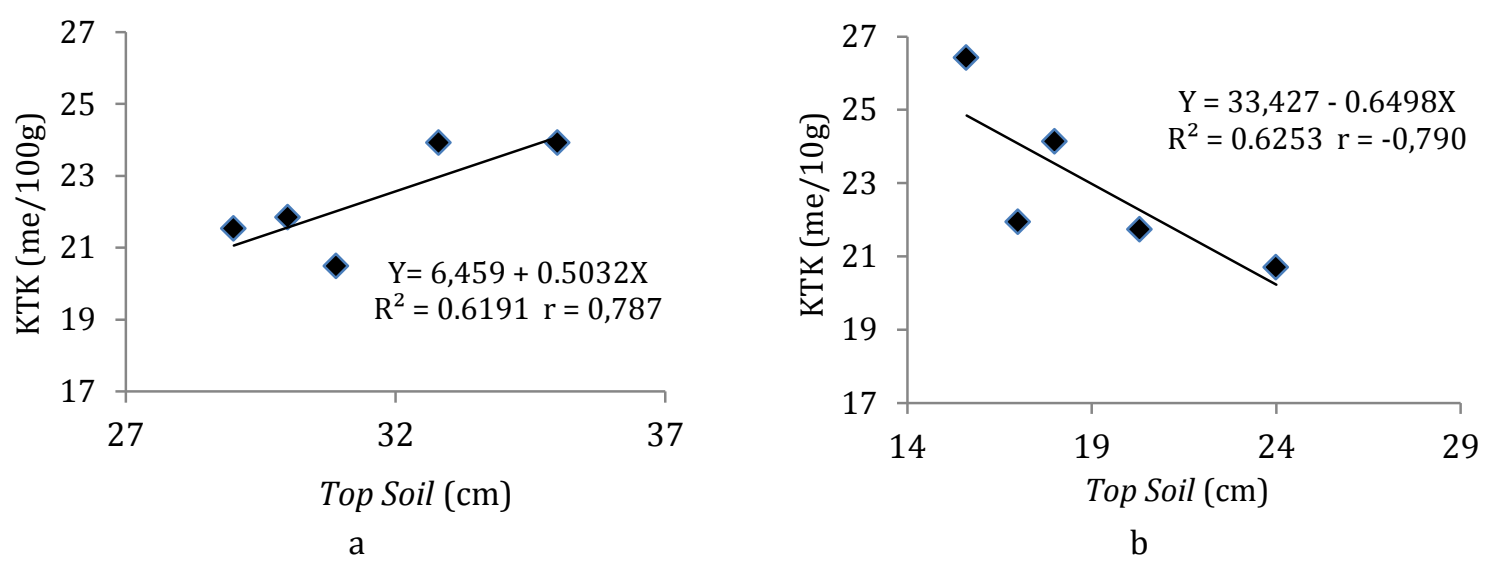

Gambar 3 Hubungan antara Ketebalan Topsoildengan KTK Tanah di Lereng Atas (a), Lereng Tengah (b)

Berdasarkan Gambar 3 (a) koefisien korelasi dengan nilai $r=0,787$ menunjukkan bahwa terdapat hubungan yang kuat antara ketebalan topsoildengan KTK tanah pada lereng atas, dimana KTK tanah sebesar $61,91 \%$ dipengaruhi oleh ketebalan topsoildan sisanya dipengaruhi oleh faktor lain yang belum diketahui. Hubungan yang terjadi pada posisi lereng atas adalah semakin tebal topsoilmaka semakin tinggi nilai KTK tanah pada daerah tersebut.

Gambar 3 (b) menjelaskan koefisien korelasi dengan nilai $r=-0,790$ menunjukkan bahwa terdapat hubungan yang kuat antara ketebalan topsoildengan KTK tanah pada lereng tengah, dimana nilai KTK tanah sebesar 62,53\% dipengaruhi oleh ketebalan topsoildan sisanya dipengaruhi oleh faktor lain yang belum diketahui. Dapat dilihat pada Gambar 3. bahwa hubungan yang terjadi pada posisi lereng tengah adalah semakin tebal topsoilmaka semakin rendah nilai KTK tanah pada daerah tersebut.

Nilai KTK tanah pada posisi lereng tengah semakin menurun karena pada posisi lereng ini memiliki ketebalan topsoilyang paling rendah sehingga kandungan liat dan bahan organik yang lebih sedikit daripada lereng lainnya. Pada lereng ini terjadi proses erosi yang cukup besar seperti proses pengangkutan dan transportasi bahan-bahan tanah, sehingga pada daerah ini memiliki ketebalan topsoilyang rendah sehingga sifatsifat tanah pada daerah ini kurang baik.

Nilai KTK tanah menunjukkan kemampuan tanah dalam menjerap dan mempertukarkan kation dalam tanah. Semakin tinggi nilai KTK tanah maka semakin banyak kation yang dapat ditukar. Tinggi rendahnya nilai KTK tanah ditentukan oleh kandungan liat dan bahan organik pada tanah tersebut. Tanah yang memiliki nilai KTK tinggi akan menyebabkan lambatnya perubahan $\mathrm{pH}$ tanah. Tanah-tanah dengan kandungan bahan organik atau kandungan liat yang tinggi akan memiliki nilai KTK yang lebih tinggi daripada tanah-tanah dengan kandungan bahan organik yang rendah dan tanah-tanah yang berpasir (Hardjowigeno, 2003).

\section{KESIMPULAN}

Posisi lereng berpengaruh terhadap ketebalan top soil, tetapi tidak berpengaruh terhadap tekstur tanah, bobot isi tanah, $\mathrm{pH}$ tanah, kandungan C-organik tanah dan KTK tanah. Pada lereng atas terdapat hubungan yang kuat antara ketebalan topsoil dengan fraksi debu $(r=0,826)$, terdapat hubungan yang kuat antara ketebalan topsoil dengan fraksi liat $(r=-0,823)$, terdapat hubungan yang kuat antara ketebalan topsoil dengan KTK tanah $(r=0,787)$. Pada lereng tengah terdapat hubungan yang kuat antara ketebalan topsoildengan $\mathrm{pH}$ tanah $(\mathrm{r}=0,872)$, 
terdapat hubungan yang kuat antara ketebalan topsoildengan KTK tanah $(\mathrm{r}=$ $0,790)$. Pada lereng bawah terdapat hubungan yang kuat antara ketebalan topsoil dengan $\mathrm{pH}$ tanah $(r=-0,870)$.

\section{DAFTAR PUSTAKA}

Arsyad, S. 2010. Konservasi Tanah dan Air. Institut Pertanian Bogor, Bogor. Cetakan Ketiga.

Asdak, C. 2002. Hidrologi dan Pengelolaan Daerah Aliran Sungai. Gajah Mada University Press, Yogyakarta.

Banuwa, I.S. dan H. Buchari. 2010. Ctersimpan pada berbagai pola usahatani berbasis kopi. Dalam Sinukaban, N dkk (Eds). Prosiding Seminar Nasional Masyarakat Konservasi Tanah dan Air Indonesia. Jambi, 24-25 Nopember 2010. Hal. 3595 - 3-609.

Hanafiah, K. A. 2007. Dasar-Dasar Ilmu Tanah. PT. Raja Grafindo Persada, Jakarta.

Harjdowigeno, S. 2003. Klasifikasi Tanah dan Pedogenesis. Akademika Pressindo, Jakarta.

Harjdowigeno, S. 2010. Ilmu Tanah. Akademika Pressindo, Jakarta.

Indranada, H. K. 1994. Pengelolaan Kesuburan Tanah. Bumi Aksara. Jakarta

Sutanto, R. 2005. Dasar-Dasar Ilmu Tanah Konsep dan Kenyataan. Kanisius, Yogyakarta.

Thomas, G.W. and Hargrove, W.L. 1984. The chemistry of soil acidity. In Adams, F (Ed). Soil Acidity and Liming Second edition. Wisconsin (USA): American Society of Agronomy Inc. 